\title{
First record of a bee fly (Diptera: Bombyliidae) parasitic on antlions (Myrmeleontidae) in Russia
}

\author{
Первый случай паразитирования мух-жкужжкал (Diptera: \\ Bombyliidae) на муравьинах мьвах (Myrmeleontidae) в России
}

\author{
E.P. Nartshuk ${ }^{1}$, V.A. Krivokhatsky ${ }^{1}$, N.L. Evenhuis ${ }^{2}$ \\ Э.П. Нарчук ${ }^{1}$, В.А. Кривохатский ${ }^{1}$, Н.А. Эвенуис ${ }^{2}$
}

\footnotetext{
Zoological Institute of Russian Academy of Sciences, Universitetskaya nab. 1, St. Petersburg 199034, Russia. E-mail: chlorops@zin.ru, krivokhatsky@yandex.ru

1 Зоологический институт РАН, Университетская наб. 1, Санкт-Петербург 199034, Россия.

${ }^{2}$ Bishop Museum, 1525 Bernice Street, Honolulu, Hawaii 96817, USA. E-mail: neale@bishop.museum.org
}

KEY WORDS: bee flies, antlion, parasite, Dagestan, Russia.

КЛЮЧЕВЫЕ СЛОВА: мухи-жужжала, муравьиные львы, паразиты, Дагестан, Россия.

ABSTRACT. A review of the bee flies (Diptera: Bombyliidae) parasitic on preimaginal stages of antlion (Myrmeleontidae) is given. A first case of Micomitra stupida (Rossi, 1790) as a parasite of an antlion, probably Euroleon nostras (Geoffroy in Fourcroy, 1785), in Dagestan, Russia is presented. The distribution of $M$. stupida is mapped.

РЕЗЮМЕ. Дан обзор паразитирования мух-жужжал (Diptera: Bombyliidae) на муравьиных львах (Myrmeliontidae). Описан первый случай паразитирования Micomitra stupida (Rossi, 1790) на муравьином льве, предположительно Euroleon nostras (Geoffroy in Fourcroy, 1785), в Дагестане, Россия. Распространение Micomitra stupida картировано.

Bee flies (Bombyliidae) are a biodiverse family with species that are parasitoids or predators as larvae and nectarivorous as adults. The family distributed globally except Antarctica with more than 4.780 described species [Evenhuis, Greathead, 2015]. The larvae of Bombyliidae are parasitoids or predators of preimaginal stages of other insects or spider's egg masses. Many species are endoparasites of bees, solitary wasps, larvae and pupae of Lepidoptera and Coleoptera, hyperparasites of Diptera and Hymenoptera developing in caterpillars. A few species are known as parasites of antlions. Bombyliidae are the only known Diptera specifically parasitic on antlions.

Smith [1934] was the first who recorded Dipalta serpentina Osten-Sacken, 1877 (Anthracinae, Bombyliidae) as a parasite of Myrmeleon immaculatus De
Geer, 1773 in North America, later Leech and MacDonald-Leech [1989] reared the same species of Bombyliidae from a pupa in the cocoon of Myrmeleon immaculatus in California. Steffan [1967] published a case of parasitism of Bombyliidae on antlions in the Old World. He bred four specimens of Micomitra stupida (Rossi, 1790) from cocoons of Euroleon nostras (Geoffroy in Fourcroy, 1785), Myrmeleon inconspicuous Rambur, 1842, Megistopus flavicornis (Rossi, 1790) and Creoleon lugdunensis (Villers, 1789) on the south of France. Du Merle [1975] published a review of the literature of host and preimaginal stages of Bombyliidae. Pantaleoni [1984] recorded rearing the bombyliid Pterobates sp. from pupae of Myrmeleon inconspicous Rambur, 1842 in Italy. Baba et al. [1987] recorded Villa myrmeleonostena (Baba, 1953) as a parasitoid of an antlion in Japan. Zaitzev [1998] described a case of parasitism of Micomitra stupida on an undetermined antlion in Tajikistan. Adults of those Bombyliidae emerged in August. Miksch [1993] described from Greece adults and pupae of Oestranthrax myrmecaeluri Miksch, 1993 bred from the larva of antlion Myrmecaelurus trigrammus (Pallas, 1771), the first record of antlion parasitism in the genus Oestranthrax Bezzi, 1923. In her observations, usually the larvae of the $3^{\mathrm{d}}$ stage, and sometimes larvae of the $2^{\mathrm{d}}$ stage were parasitized, antlion larvae completed development after cocoon formation, and adult Bombyliidae emerged from cocoons in August. Matsuda et al. [1998] described the development of larvae of Villa myrmeleonostena (Baba, 1953) in the larvae and pupae of Myrmeleon bore (Tjeder, 1941) in Japan. They

How to cite this article: Nartshuk E.P., Krivokhatsky V.A., Evenhuis N.L. 2019. First record of a bee fly (Diptera: Bombyliidae) parasitic on antlions (Myrmeleontidae) in Russia // Russian Entomol. J. Vol.28. No.2. P.189 -191. doi: 10.15298/rusentj.28.2.13 
found that larvae of Villa Lioy, 1864 of the first stage develop as endoparasites. Larvae of the third stage develop as ectoparasites on the pupae of antlion, which are inside of the cocoons. Marshall [2012] mentioned an unnamed species of Anthrax Scopoli, 1763 reared from an antlion. Uchoa and Missirian [2014] reared parasites of an undetermined species of Paravilla Painter, 1933 from Myrmeleon brasiliensis in Brazil. Evenhuis [2017] described a new species of Chrysanthrax (C. pennyi) parasitic on an undetermined species of Myrmeleon from Costa Rica; and Evenhuis [2018] described the new genus and species Taiwanon phormae from Taiwan, parasitic on the non-pit building antlion, Dendroleon esbenpeterseni Miller et Stange, 1999.

We recently received 5 specimens of Bombyliidae bred from cocoons of antlion, in Sarykum, Dagestan, Russia. All specimens emerged on 14.08 (year was not written), leg. G. Khabiev. G. Khabiev noted on the labels the antlion's name as Euroleon nostras. Unfortunately, the cocoons with larval exuviae of the antlion as well as the pupal exuviae of flies were not kept and exact determination of the antlion is impossible. Nevertheless, within the known fauna of Sarykum Dune [Ilyina et al., 2014], 7 species of antlions with propor- tionate sizes of cocoons occur there, consequently Euroleon nostras (Geoffroy in Fourcroy, 1785) could be one of the potential hosts of bee flies reared from collections made in Sarykum, Dagestan. Other candidates to the host role are the pit-building antlions Myrmeleon immanis Walker, 1853, M. inconspicuus Rambur, 1842, Myrmecaelurus trigrammus (Pallas, 1771), and the non-pit building larvae Distoleon tetragrammicus (Fabricius, 1798), Macronemurus bilineatus Brauer, 1868 and Creoleon plumbeus (Olivier, 1811).

The bee flies were determined as Micomitra stupida (Rossi, 1790). This species is widely distributed in the Palearctic Region: Armenia, Austria, Azerbaijan, Egypt, Finland, France, Germany, Greece (incl. Naxos), Georgia, Hungary, Iran, Israel, Italy (incl. Sardinia, Sicily), Kazakhstan, Kyrgyz Republic, Libya, Poland, Portugal, Romania, Russia (vic. Sankt Petersburg, the Crimea, Orenburg Province and Dagestan), Spain, Sweden, Switzerland, Tajikistan, Turkey, Turkmenistan, Uzbekistan [Zaitzev, 1966; Evenhuis, Greathead, 2015 and data from the collection of the Zoological institute of Russian Academy of Sciences in St. Petersburg] (Map).

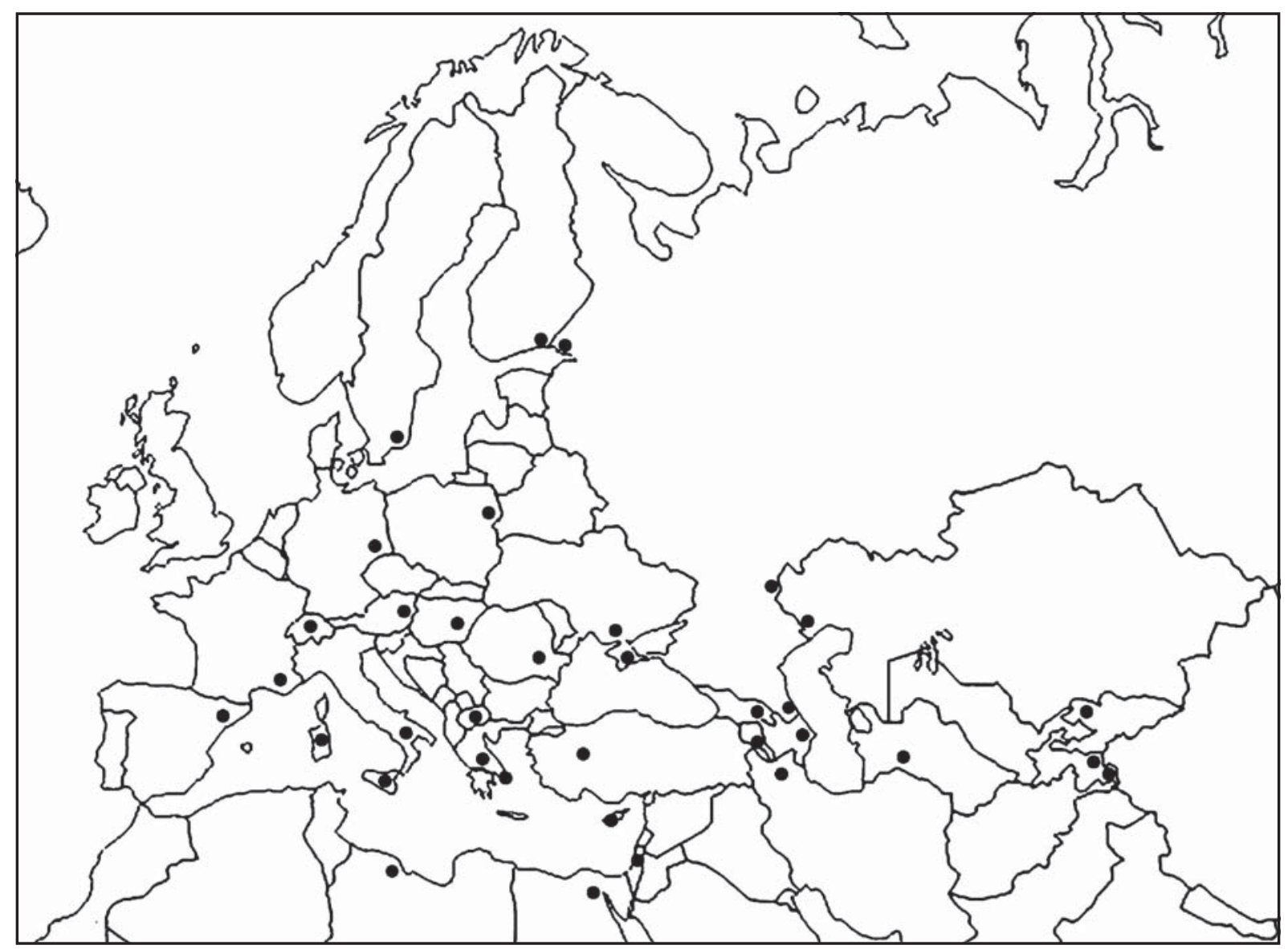

Map. Distribution of Micomitra stupida (Rossi, 1790) on data in Zaitzev [1966]; Evenhuis, Greathead [2015] and the collection of the Zoological institute of Russian Academy of Sciences.

Карта. Распространение Micomitra stupida (Rossi, 1790) по данным из Зайцева [1966]; Evenhuis, Greathead [2015] и коллекционным материалам Зоологического института РАН. 


\section{Conclusion}

To the present day species from the genera Micomitra Bowden, 1964, Oestranthrax Bezzi, 1923, Villa, Anthrax Scopoli, 1763, Pterobates Bezzi, 1921, and Taiwanon Evenhuis, 2018 (Diptera: Bombyliidae) are known as parasites of antlions in the Old World; and Chrysanthrax Osten Sacken, 1886, Dipalta Osten-Sacken, 1877, and Paravilla, are ant lion parasites in the New World. All these genera belong to the subfamily Anthracinae, but to different tribes. The subfamily Anthracinae is the largest among Bombyliidae and includes nearly half of all species of the family and many of the largest and most widespread genera.

The larvae of bee flies are parasites of antlion larvae that live in pits or free in sand. We propose that, like in other cases, the $3^{\mathrm{d}}$ stage larva of antlions are attacked by fly larva. When larva of the antlion builds the cocoon and molts to the pupal stage, the fly larva metamorphoses. In coevolution, the tendency to a primary connection of bee flies with pit-building antlions could be proposed, the flies of which are able to locate hosts by searching for sands with colonies of antlion larvae, after which the female shoots the eggs to the pits while hovering overhead. Parasitism on the non-pit building antlion larvae is not a next step in evolution, but is instead an independently derived behavior.

Acknowledgements. The study was performed in the frames of the state research project AAAA-A19. 119020690082-8, and supported by the Presidium RAS program no. 41 "Biodiversity of natural systems and biological sources of Russia".

\section{References}

Baba K., Nagatomi A., Nagatomi H. \& Evenhius N.L. 1987. Redescription of Villa myrmeleonostena (Insecta, Diptera, Bombyliidae) a parasitoid of antlion in Japan // Zoological Science. Vol.4. P.903-911.

Du Merle P. 1975. Les hôtes et les stades pré-imaginaux des Diptères Bombyliidae: revue bibliographique annotée // Bulletin de la
Section Regionale Ouest Palearctique (Organisation Internationale de Lutte Biologique). Vol.4. P.1-289.

Evenhuis N.L. 2017. A new species of Chrysanthrax Osten-Sacken (Diptera: Bombyliidae) from Costa Rica parasitic on an antlion (Neuroptera: Myrmeleontidae) // Zootaxa. Vol.4363. P.583-588. Evenhuis N.L. 2018. A new genus and species of Villoestrini Hull (Diptera: Bombyliidae) from the Oriental Region parasitic on antlions (Neuroptera: Myrmeleontidae), with a key to genera in the tribe // Bishop Museum Occasional Papers. Vol.124. P.110 .

Evenhuis N.L., Greathead D.J. 2015. World catalog of bee flies (Diptera: Bombyliidae). Revised September 2015. Available at: http:// hbs.bishopmuseum.org/bombcat/bombcat-revised2015.pdf.

Ilyina E.V., Khabiev G.N., Krivokhatsky V.A. 2013 [2014]. [Myrmeleontoid lacewings (Neuroptera: Myrmeleontidae, Ascalaphidae) of Sarykum and environs] // Trudy gosudarstvennogo prirodnogo zapovednika "Dagestanskyi". Vol.5. P.32-36 [in Russian].

Leech R., MacDonald-Leech J.U. 1989. Dipalta serpentina OstenSacken (Diptera: Bombyliidae) as a predator on pupae of the antlion Myrmeleon immaculatus De Geer (Neuroptera: Myrmeleontidae) in California // The Canadian Entomologist. Vol.121. P.727-728.

Marshall S.A. 2012. Flies. The natural history and diversity of Diptera. Firefly books. 616 pp.

Matsuda Ò., Ohno H., Sakamoto M. 1998. Rate of parasitism of the antlion larvae, Myrmeleon bore (Neuroptera: Myrmeleontidae) by the bee fly Villa myrmeleonostena (Diptera: Bombyliidae) // Entomological Science. Vol.1. No.3. P.321-325.

Miksch G. 1993. Oestranthrax myrmecaeluri n. sp. (Diptera: Bombyliidae) aus Griechenland mit Angabe des Wirtes // Stuttgarter Beiträge zur Naturkunde. Serie A. (Biologie). Nr.493. S.7-9.

Pantaleoni R.A. 1984. Note su alcuni parasiti (s.1.) di Neurotteri Planipenni con segnalazione del ritrovamento di Acari forcstici su di un Crisopide // Bollettino dell'1stituto di Enlomologia della Universita degli studi di Bologna. Vol.38. P.193-203.

Smith R.C. 1934. Notes on the Neuroptera and Mecoptera from Kansas // Journal of the Kansas Entomological Society. Vol.7. P.120-145.

Steffan J.R. 1967. Exoprosopa stupida (Rossi) parasite de formilions dans l'Ancien monde (Dipt. Bombyliidae) // L'Entomologiste. Vol.23. No.3. P.78-80.

Uchoa M.A., Missirian G.L.B. 2014. Myrmeleon brasiliensis's parasitoids (Neuroptera: Myrmeleontidae) in the South Pantanal, Brazil // Florida Entomologist. Vol.97. P.313-316.

Zaitzev V.F. 1966. [Parasitic flies of the family Bombyliidae(Diptera) in the fauna of the Transcaucasia] // A.A. Stackelberg (ed.). Opredelitely po faune SSSR, izdavaemye Zoologicheskim institutom AN SSSR. Vol.93. 375 pp. [In Russian]

Zaitzev V.F. 1998. On the morphology of the pupae of flies of the family Bombyliidae (Diptera). III. // Entomological review. Vol.78. Nr.5. P.613-619. 